\title{
Evaluation of the effectiveness of remdesivir in treating severe COVID-19 using data from the ISARIC WHO Clinical Characterisation Protocol UK:
}

\author{
a prospective, national cohort study.
}

\section{Short Running title: ISARIC4C Remdesivir effectiveness study}

\section{$\underline{\text { Authors }}$}

Arch $\mathrm{BN}^{1}$, Kovacs $\mathrm{D}^{2 *}$, Scott $\mathrm{JT}^{3^{*}}$, Jones $\mathrm{AP}^{1}$, Harrison $\mathrm{EM}^{4}$, Rosala-Hallas $\mathrm{A}^{1}$, Gamble $\mathrm{CG}^{1}$, Openshaw $\mathrm{PJM}^{5}$, Baillie $\mathrm{JK}^{6}$, Semple $\mathrm{MG}^{7,8}$ on behalf of ISARIC4C Investigators

*Joint $2^{\text {nd }}$ authors

\section{$\underline{\text { Affiliations }}$}

1. Liverpool Clinical Trials Centre, Clinical Directorate, Faculty of Health and Life Sciences, University of Liverpool, UK.

2. Institute of Biodiversity, Animal health and Comparative Medicine, University of Glasgow, Glasgow, UK

3. MRC-University of Glasgow Centre for Virus Research, Glasgow, UK

4. Centre for Medical Informatics, The Usher Institute, University of Edinburgh, Edinburgh, UK

5. National Heart and Lung Institute, Imperial College London, London, UK

6. Roslin Institute, University of Edinburgh, Edinburgh, UK

7. Health Protection Research Unit in Emerging and Zoonotic Infections, Institute of Infection, Veterinary and Ecological Sciences, Faculty of Health and Life Sciences, University of Liverpool, Liverpool, UK.

8. Department of Respiratory Medicine, Alder Hey Children's Hospital, Liverpool, UK.

\section{Corresponding author}

Barbara Arch. Liverpool Clinical Trials Centre, University of Liverpool, Institute in the Park, Alder Hey Childrens Hospital, Eaton Road, Liverpool, L12 2AP.

Email: barbara.arch@liverpool.ac.uk, Tel: +44(0)151 7958751

\section{Word Count}

Abstract 267/300

Manuscript (excluding Research in Context Panel) 3,579/3,500

NOTE: This preprint reports new research that has not been certified by peer review and should not be used to guide clinical practice. 
medRxiv preprint doi: https://doi.org/10.1101/2021.06.18.21259072; this version posted June 21 , 2021. The copyright holder for this preprint (which was not certified by peer review) is the author/funder, who has granted medRxiv a license to display the preprint in perpetuity.

It is made available under a CC-BY-NC-ND 4.0 International license .

\begin{abstract}

\section{Background}

Remdesivir was given UK early-access approval for use in COVID-19 in people aged 12 years and older on $26^{\text {th }}$ May 2020 on the basis of unmet clinical need. Evidence on the side effects, complications of therapy and effectiveness of this therapy is lacking or conflicting.
\end{abstract}

\title{
Methods
}

Adults with severe COVID-19 treated with remdesivir were compared with propensity-score matched controls, identified from the ISARIC WHO Clinical Characterisation Protocol study of UK hospitalised patients with COVID-19. Remdesivir patients were matched to controls according to baseline underlying 14-day mortality risk. The effect of remdesivir on short-term outcomes was investigated (primary outcome: 14-day mortality). Effect sizes were estimated and adjusted for potential confounders using multivariable modelling.

\section{Results}

1,549 patients given remdesivir and 4,964 matched controls were identified satisfying inclusion and exclusion criteria. The balance diagnostic threshold was achieved. Patients had symptoms for a median of 6 days prior to baseline; $62 \%$ were male, with mean (SD) age $63 \cdot 1(15 \cdot 6)$ years, and $80 \%$ categorised as 'White' ethnicity. Fourteen-day mortality was not statistically significantly associated with treatment ( $9 \cdot 3 \%$ remdesivir vs. $11 \cdot 9 \%$ controls, odds-ratio $0 \cdot 80$, [95\% CI 0.60-1·07], $\mathrm{p}=0 \cdot 116$, adjusted for age, sex, number of key comorbidities, dexamethasone use, and diagnosis of viral pneumonia.

\section{Findings}

Treatment with remdesivir was not associated with a reduction in mortality in our primary endpoint at 14 days.

\section{Interpretation}

Remdesivir did not significantly improve mortality in this study. The findings are subject to the limitations of an observational study. Balance was achieved for measured baseline factors, but unmeasured confounders may account for observed treatment effect sizes.

\section{Funding}

Medical Research Council UK \& National Institute of Health Research 
medRxiv preprint doi: https://doi.org/10.1101/2021.06.18.21259072; this version posted June 21 , 2021. The copyright holder for this preprint (which was not certified by peer review) is the author/funder, who has granted medRxiv a license to display the preprint in perpetuity.

It is made available under a CC-BY-NC-ND 4.0 International license.

\section{Research in context}

\section{Evidence before this study}

At the time of designing this study, two clinical trials measuring the efficacy of remdesivir as a therapeutic in treating SARS COV-2 had published results: ACTT-1 and SOLIDARITY. ACTT-1 suggested that for those who required supplemental oxygen but not ventilation at baseline, remdesivir reduced time-to-recovery (rate ratio 1·45, [95\% CI: 1·19-1·79]), improved clinical status at 15 days (proportional odds ratio $1 \cdot 6[1 \cdot 2-2 \cdot 3]$ ), and improved mortality by both 15 days (hazard ratio $0 \cdot 28[0 \cdot 12$ $0 \cdot 66])$ and 29 days $(0 \cdot 30$ [0.14-0.64]) compared with a placebo. SOLIDARITY did not find any evidence of benefit for remdesivir in these same types of patients - it reported on time-to-recovery, and 28-day mortality, compared with the local standard of care.

\section{Added value of this study}

This study presents real-world data on the effectiveness of remdesivir use during a non-surge phase of the pandemic in the UK, specifically looking at patients for whom the ACTT-1 trial suggested would be most likely to benefit from remdesivir.

\section{Implications of all the available evidence}

We show that during the pandemic, remdesivir was given to a wide demographic of patients in the UK (on average older than those in clinical trials). At 14-days post baseline no reduction in absolute mortality was observed. Propensity score matching achieved balance for measured baseline variables. However as with all observational studies, differences between the groups in unmeasured variables that may influence clinicians but were not recorded in our study, are plausible. 
medRxiv preprint doi: https://doi.org/10.1101/2021.06.18.21259072; this version posted June 21, 2021. The copyright holder for this preprint (which was not certified by peer review) is the author/funder, who has granted medRxiv a license to display the preprint in perpetuity.

It is made available under a CC-BY-NC-ND 4.0 International license.

\section{Introduction}

Several therapeutic drugs licensed for use in other conditions have been trialled in the treatment of severe COVID-19. Remdesivir (Gilead Sciences, Inc.), was approved for use in people aged 12yrs and older affected with severe COVID-19 by the United Kingdom's (UK) Medicines and Healthcare products Regulatory Agency (MHRA) under their Early Access to Medicine Scheme (EAMS) from $26^{\text {th }}$ May 2020. EAMS status was withdrawn in July 2020, because remdesivir was commissioned for routine use in severe COVID-19 following an evidence review ${ }^{1}$ by the National Institute for Health and Care Excellence (NICE). The data collection initiated to evaluate remdesivir has continued.

\section{Clinical trial evidence for remdesivir use}

Remdesivir is a broad-spectrum antiviral drug that has shown activity against Ebola virus in vitro and in non-human primates. ${ }^{2}$ It is an adenosine nucleotide prodrug administered via intravenous infusion, and once it is metabolised into its active form ${ }^{3}$, it inhibits the viral RNA-dependent RNA polymerase ${ }^{4}$, a conserved enzyme involved in viral RNA synthesis. Remdesivir has demonstrated in vitro efficacy against other emerging coronaviruses, such as MERS-CoV and SARS-CoV-1 ${ }^{5,6}$, and SARS-CoV-2 ${ }^{7-}$ 11. The half-effective concentration (EC50) values against SARS-CoV-2 were below $5 \mu \mathrm{M}$. This promising EC50 combined with high ( $>100$ ) safety indices in cells, made remdesivir one of the principal compounds of interest for a clinical trial early in the pandemic. While in vivo studies also showed clinical benefits $^{2,12}$, there are limits to what can be extrapolated from the animal models due to important differences in the pharmacokinetics of the drug and disease course, particularly in mice. ${ }^{13}$ The pharmacokinetics of remdesivir have been reported in healthy adults, showing a favourable profile, ${ }^{14}$ but they are yet to be reported in severely ill patients. At the time of design of this study, findings for two key clinical trials (ACTT-1 ${ }^{15,16}$, and SOLIDARITY ${ }^{17,18}$ ) had been publicised (see Research in Context panel).

\section{Methods}

\section{Study design and participants}

We used data from a prospective observational cohort study of UK patients hospitalised, using a unique dataset consisting of data collected using the ISARIC WHO CCP-UK protocol. ${ }^{19,20}$ Study materials including protocol, revision history, case report forms (CRFs), study information and consent forms, are available online ${ }^{20}$ Ethical approval for data collection was given by the South Central - Oxford C Research Ethics Committee in England (Ref: 13/SC/0149) and by the Scotland A Research Ethics Committee (Ref: 20/SS/0028). Under the Control of Patient Information (COPI) notice 2020 for urgent public health research, processing of demographic and routine clinical data from medical records for research does not require consent in England and Wales. In Scotland, a waiver for consent was obtained from the Public Benefit and Privacy Panel. The patient population of interest was those who at baseline 
medRxiv preprint doi: https://doi.org/10.1101/2021.06.18.21259072; this version posted June 21, 2021. The copyright holder for this preprint

(which was not certified by peer review) is the author/funder, who has granted medRxiv a license to display the preprint in perpetuity.

It is made available under a CC-BY-NC-ND 4.0 International license

would have been eligible to be initiated on remdesivir and classified at clinical status level 5 of an 8point ordinal scale (hospitalised, requiring oxygen, but not requiring ventilation) (see below for full definitions of baseline and inclusion/exclusion criteria). The study period was patient baseline between $26^{\text {th }}$ May 2020 and $30^{\text {th }}$ November 2020, with 28 days follow-up post baseline (see below). Patients that initiated remdesivir treatment within 24 hours of baseline were compared with a propensity-score matched control group that received no remdesivir during hospitalisation. We followed the Strengthening the Reporting of Observational Studies in Epidemiology (STROBE) Statement checklist to guide transparent reporting of this study.

\section{Procedures}

Patients were eligible for inclusion whether their COVID-19 was hospital or community acquired (hospital: symptom onset at least 5 days after hospital admission; community: admitted with symptoms consistent with COVID-19). They were followed up for 28 days post baseline. 'Baseline' was defined as 'date of hospital admission' for community acquired COVID-19 and 'date of a positive COVID-19 test' for hospital acquired infection. Patients were included if they satisfied all of the following: (1) Laboratory confirmed SARS-CoV-2 infection; (2) hospitalised; (3) aged $\geq 18$ years at baseline; (3) requiring supplementary oxygen (usually for hypoxaemia $\mathrm{SpO}_{2} \leq 94 \%$ ) at any time during the 24 hours post baseline; (4) remdesivir initiated $\leq 24$ hours post baseline (remdesivir group only). Patients were excluded if at least one of the following criteria were confirmed: (1) requiring any form of respiratory support ("high flow" oxygen, non-invasive, or invasive ventilation) or extracorporeal membrane oxygenation (ECMO) during first 24 hours post baseline; (2) pregnant; (3) chronic kidney disease, or a baseline estimated glomerular filtration rate (eGFR) <30; (4) remdesivir initiated $>24$ hours post baseline; (5) COVID-19 re-admission (was previously hospitalised for COVID-19); (6) missing a Day 1 Daily Treatment CRF; (7) missing 'Medication' section of the Outcome CRF.

We define two treatment groups: standard of care with remdesivir, and standard of care without remdesivir (control treatment). Guidelines in the $\mathrm{UK}^{21}$ - recommended remdesivir's use in newly hospitalised patients, no later than within 10 days of symptom onset, and only initiated in non-ventilated patients. Recommended dosing was $200 \mathrm{mg}$ on Day 1 of treatment, followed by $100 \mathrm{mg}$ daily for 4 days. Guidelines regarding recommended duration of treatment evolved over time (see appendix [p6]). Standard of care evolved over time: corticosteroids, dexamethasone and hydrocortisone, became recommended for some patients part-way through the study period. Interactions between remdesivir and these corticosteroids were not expected ${ }^{21}$ such that remdesivir patients will have received these in the same way as non-remdesivir patients. The drugs hydroxychloroquine and chloroquine phosphate were actively not recommended as concomitant medications for remdesivir from $3^{\text {rd }}$ September 2020 (Figure 2). 
medRxiv preprint doi: https://doi.org/10.1101/2021.06.18.21259072; this version posted June 21, 2021. The copyright holder for this preprint

(which was not certified by peer review) is the author/funder, who has granted medRxiv a license to display the preprint in perpetuity.

It is made available under a CC-BY-NC-ND 4.0 International license.

The control group was selected from the cohort of eligible non-remdesivir patients using propensity score matching. An optimal propensity score (log-odds of being given remdesivir at baseline) model was derived from the data using the following baseline variables as potential predictors prespecified in the statistical plan: month of baseline; ISARIC4C tier of participating centre (0/1/2); sex; age; broad ethnicity group (White/Asian/Black/Other); clinically extremely vulnerable status (yes [Any of the following: cancer, severe respiratory condition, on immunosuppression therapy, other]/none/unknown); binary indictors of the key comorbidities: diabetes, hypertension, obesity, chronic cardiac disease (CCD), chronic pulmonary disease (CPD), and asthma; where COVID was acquired (community / hospital); admitted to HDU or ICU at baseline (yes/no). A propensity score was then assigned to each patient and used to match remdesivir patients with up to four controls (see Statistical Methods below).

Data were routinely collected on patients at baseline, the first day of admission to an ICU, and then on death, discharge, or day 28 post hospitalisation depending on which was soonest. For some sites, daily CRFs for days 3, 6 and 9 were also collected. Remdesivir patients had daily CRFs completed for each day of remdesivir dosing, and on day 14 after remdesivir initiation. Data collection regarding safety was limited to a tick-box assessment of 30 complications that patients may have experienced during their hospital stay post baseline. Space was provided for free-text entry of other complications, and these were searched for text that indicated any of the 30 listed complications, and to identify commonly occurring others. There was no scope to measure severity or relatedness, and the quality of the data relied on what was recorded in medical notes. An extract of the database was made on $10^{\text {th }}$ January to assess (a) whether the sample size of eligible remdesivir patients was $>500$, and (b) the extent of missing data of key baseline variables and the primary outcome. This data extract was judged to be adequate for the purpose of our analysis. No outcome analyses were carried out prior to this decision.

The primary outcome was 14-day mortality. Secondary outcomes were: (1) time-to-recovery; (2) 28 day mortality; (3) time-to-death; (4) clinical status at day 15; (5) length of time receiving supplementary oxygen; (6) time-to-first ventilation; (7) use of non-invasive ventilation; (8) use of mechanical ventilation or ECMO; (9) acute renal injury/acute renal failure; and (10) liver dysfunction. Full definitions and rationale for the outcomes are given in the appendix [pp 3-4].

\section{Statistical Methods}

The study was planned prior to access to the data being granted and a statistical analysis plan (SAP) was published on the ISARIC website on $16^{\text {th }}$ December. ${ }^{22}$ This was subject to internal clinical and statistical review. The manufacturer was also given opportunity to comment on the SAP. This review was discretionary, and suggested revisions were considered prior to finalisation; however none were considered substantive and the proposed methodology was unchanged. 
medRxiv preprint doi: https://doi.org/10.1101/2021.06.18.21259072; this version posted June 21, 2021. The copyright holder for this preprint

(which was not certified by peer review) is the author/funder, who has granted medRxiv a license to display the preprint in perpetuity.

It is made available under a CC-BY-NC-ND 4.0 International license.

The sample size was limited by the number of patients treated with remdesivir in practice and while a formal sample size calculation was not undertaken a sample size of more than 500 patients treated with remdesivir was considered sufficient for a meaningful analysis. No upper boundary was placed on the numbers included. The number of controls eligible for the study could not be predicted, but the total was expected to be greater than the number that received remdesivir.

Remdesivir patients were matched with to up to four controls using variable-ratio nearest-neighbour propensity-score matching with a calliper width of 0.2 standard deviations. ${ }^{23}$ Controls were chosen without replacement, so could not be matched to more than one remdesivir patient. An optimal propensity score model was selected satisfying a pre-defined balance diagnostic threshold (absolute standardised difference in risk score $\mathrm{ASD}_{\mathrm{RS}} \leq 0 \cdot 1^{24}$, where risk score is the estimated underlying risk of 14-day all-cause mortality). Full details and rationale for methods are given in the appendix [p8].

Descriptive statistics were used to describe demographics, other baseline characteristics including preexisting comorbidities, treatments received during hospitalisation, and complications associated with hospitalisation. Outcomes were summarised by treatment group, but inference was obtained through multivariable modelling, adjusting for key confounders chosen a priori (sex, age-group, and number of key comorbidities), and if necessary, additional factors that on seeing the data were considered potential confounders. Models incorporated weights for the control group to account for the variable matching ratio $\left(w_{j}=1 / k_{j}\right)$ where $k_{j}$ is the number of controls matched to remdesivir patient $\left.j\right)$. Stuart ${ }^{23}$ suggests that for analysis purposes, the two groups may be treated as independent. Binary outcomes (e.g. 14-day mortality) were modelled using logistic regression; time-to-event outcomes were modelled using Cox Proportional-Hazards models (using a Landmark analysis if proportional hazards assumptions failed); the ordinal outcome - clinical status at 15 days - was modelled with ordinal logistic regression. The primary outcome analysis was subject to sensitivity analyses regarding specification of the logistic regression model: e.g. adding propensity score as a covariate, adding interactions. Propensity score matching was carried out using the package MatchIt in R v3.6.1; all other analyses were carried out using SAS v9.4.

\section{Results}

\section{Cohort ascertainment and characteristics}

A total of 39,330 unique patients were identified from a data extract made on $8^{\text {th }}$ January 2021 , with a baseline date between $26^{\text {th }}$ May and $30^{\text {th }}$ November 2020. A total of 9,278 patients satisfied inclusion/exclusion criteria, and of these, 6,513 were included in the matched analysis (see Figure 1, and Table S2). Patients included in the matched cohort came from all regions of the UK, were $62 \cdot 1 \%$ male, with mean (SD) age $63 \cdot 1(15 \cdot 6)$ years, and $79 \cdot 7 \%$ of those with ethnicity recorded were 
medRxiv preprint doi: https://doi.org/10.1101/2021.06.18.21259072; this version posted June 21 , 2021. The copyright holder for this preprint (which was not certified by peer review) is the author/funder, who has granted medRxiv a license to display the preprint in perpetuity.

It is made available under a CC-BY-NC-ND 4.0 International license.

categorised as 'White' (see Table 1). They had a median (IQR) 4C Mortality Score of $9(6,12)$, meaning that most patients were classified as at intermediate or high risk of in-hospital mortality.

An optimal propensity score model was derived, with sufficient balance between the groups $\left(\mathrm{ASD}_{\mathrm{RS}}=\right.$ $0 \cdot 1)$. In the eligible cohort, remdesivir was found to have been more likely given: later in the study period, to younger patients, those without an extreme clinical vulnerability, with obesity, who acquired COVID-19 in the community, or who were not admitted to HDU or ICU at baseline (Table S3). The fitted primary outcome risk score model results are presented in Table S4. Figure S1 presents distributions of propensity score split by group. The cohorts are well balanced with respect to baseline characteristics (Table 1) - in particular, 4C Mortality Score ${ }^{25}$ statistics were almost identical.

\section{Treatments received during hospitalisation post baseline}

The remdesivir group were generally more medicated post baseline than controls. They were more likely to have been given dexamethasone $(93.9 \%$ vs. $61 \cdot 7 \%)$ or antibiotics $(89.7 \%$ vs $79 \cdot 8 \%)$ during hospitalisation. Use of at least one corticosteroid other than dexamethasone was similar in the two groups ( $9 \cdot 4 \%$ vs $10 \cdot 7 \%)$. In both groups, the use of antiviral agents other than remdesivir was rare $3.0 \%$ of the control group were known to have received an antiviral agent (Table S5). Dexamethasone use was identified as a factor that should be adjusted for in all inferential analyses, given its known efficacy as a therapeutic in treating COVID-19.

\section{In-hospital complications}

Data on complications was recorded for 6,190 (95.0\%) of the matched cohort (remdesivir: 1,504, control: 4,686). The most prevalent complications were viral pneumonia (61.9\%), bacterial pneumonia $(11 \cdot 8 \%)$, hyperglycaemia $(11 \cdot 0 \%)$, acute renal injury/failure $(8 \cdot 9 \%)$, anaemia $(8 \cdot 1 \%)$ and acute respiratory distress syndrome (ARDS) (7.2\%) (Table S6). The remdesivir group had proportionally higher recorded viral pneumonia ( $75 \cdot 2 \%$ vs $57 \cdot 6 \%$ ), hyperglycaemia (17.8\% vs $8 \cdot 8 \%$ ), and ARDS (11.4\% vs $5 \cdot 9 \%$ ). Liver dysfunction (a secondary outcome) was significantly more common in remdesivir treated cases ( $8 \cdot 6 \%$ vs $5 \cdot 4 \%$, adjusted odds ratio (OR): $1 \cdot 51,95 \%$ CI: $1 \cdot 18-1 \cdot 92, p=0 \cdot 0009)$. Acute renal injury/failure was not associated with treatment group $(0.93,0.75-1 \cdot 16, \mathrm{p}=0.53)$. No assessment could be made of relatedness nor severity of observed complications as data for this purpose were not collected.

\section{Primary Outcome}

A total of $140 / 1,507(9 \cdot 3 \%)$ patients in the remdesivir group and 565/4,734 (11.9\%) patients in the control group died within 14 days of baseline. 6,202 patients were included in a logistic regression model (Table 2). The OR of death at 14 days for remdesivir vs controls, adjusted for age, sex, number 
medRxiv preprint doi: https://doi.org/10.1101/2021.06.18.21259072; this version posted June 21, 2021. The copyright holder for this preprint (which was not certified by peer review) is the author/funder, who has granted medRxiv a license to display the preprint in perpetuity.

It is made available under a CC-BY-NC-ND 4.0 International license .

of comorbidities, dexamethasone use, and viral pneumonia was $0 \cdot 80$ with $95 \% \mathrm{CI}(0 \cdot 60-1 \cdot 07), \mathrm{p}=0 \cdot 116$. Sensitivity analyses did not change inference (appendix [p15]).

\section{Secondary Outcomes}

Time-to-recovery was found to vary with time and treatment (Figure 3A). During days 1-5, recovery was more likely in the control group; during days 6-8 there was no treatment effect; and for days 9-28, remdesivir was associated with a faster recovery (Table 3). Median (IQR) time to recovery was 9 (910) days for remdesivir, and 8 (8-9) days for controls. There is evidence to suggest that reduction in 28day mortality is associated with remdesivir (Table 2): the p-value is 0.03 , but uncorrected for multiplicity; this can be interpreted as an estimated 36 (95\% CI: 20-290) patients needed to treat to prevent one death. Time-to-death over these 28 days was not significantly associated with treatment group (Figure 3B, Table 3). Five clinical status classifications were derivable at day 15 (appendix [pp 15-16]). Ordinal regression of this outcome indicates no evidence of an association with treatment group (Table 2). The proportional odds assumption was checked and found to hold. Overall, by day 15 most patients had improved clinical status compared with baseline: 1,106/1,549 (71.4\%) remdesivir vs. 3,303/4,964 (66.5\%) controls. Non-invasive ventilation was more likely in the remdesivir group (Table 2). Remdesivir patients required more invasive mechanical ventilation or ECMO; and where data were available, median (IQR) duration of these interventions in days were $10(5,16)$ for remdesivir, and 6 $(3,14)$ for controls. Two outcomes could not be derived due to insufficient daily CRF data: length of time requiring supplementary oxygen, and time-to-first-ventilation.

\section{Discussion}

In this analysis of data from a large UK-wide study, we found that remdesivir use was not statistically significantly associated with improved 14-day mortality. There was an absolute difference in incidence of 2.6 percentage points in favour of remdesivir, but this was not statistically significant after adjusting for potential confounders. The confidence interval for the adjusted odds-ratio indicated considerable uncertainty regarding potential effect of remdesivir of a $40 \%$ reduction, to having no effect. A small reduction in 28-day mortality was detected, though as a secondary outcome, this result should be considered hypothesis generating. Our study does not exclude the possibility that effectiveness might be present in specific patient subgroups.

Our study population was representative of severe COVID-19 patients of all ages, treated in hospitals across the whole UK, predominantly of white ethnic background, and male. Compared with both the ACTT- $1^{15}$ and SOLIDARITY ${ }^{17}$ trials, our cohort was older, and less ethnically diverse. As age is a key factor in risk of death from COVID-19 absolute survival outcomes presented here should not be compared directly with the rates published in these trials. Patients in our study received many types of 
medRxiv preprint doi: https://doi.org/10.1101/2021.06.18.21259072; this version posted June 21, 2021. The copyright holder for this preprint

(which was not certified by peer review) is the author/funder, who has granted medRxiv a license to display the preprint in perpetuity.

It is made available under a CC-BY-NC-ND 4.0 International license .

treatment during hospitalisation, but the data do not indicate when these treatments were received, nor the dose, nor duration. Use of other antivirals was rare - the control group can be considered a 'Non anti-viral therapeutics' group. There is an indication that dexamethasone use (and by implication corticosteroid use) was greater in the remdesivir group, and also use of antibiotics. Complications during hospitalisation indicated some imbalance in the groups. The remdesivir group had higher recorded prevalence of viral pneumonia. This measure is difficult to interpret, and arguably our inclusion criteria define patients that were presenting with viral pneumonia at baseline. It may have little meaning recorded in the complication CRF, or may have been a proxy for greater baseline severity, or a secondary effect to the antiviral, though there is less biological plausibility for the latter. Hyperglycaemia, ARDS, and liver dysfunction were also more observed in the remdesivir group. One in eleven patients in our cohort were recorded as suffering from acute renal injury or failure, but this was similar in the two groups. NIV usage was more likely in the remdesivir group. This could represent a higher level of illness in this group, which was not apparent from the baseline data. Alternatively, it could represent a lower threshold for escalation of care in this group, or a perception that escalation was less likely to be futile in this group. See appendix p17 for further discussion regarding secondary outcomes.

This analysis used data from a prospective observational study, using routine care data collected during a pandemic. There are limitations in that effectiveness estimates are not from randomised patients, and the data collected reflect local practice by the clinical teams at numerous hospital sites. The study was designed pragmatically to be simple enough to be rapidly implemented, using data that were being collected under a generic protocol. The analysis was planned and made open for comment prior to any data being provided for analysis. Data completeness for baseline characteristics and final clinical outcomes were found to be extremely good thanks to the diligence of participating sites throughout the country. Daily follow-up data was less available than expected, and this meant that two outcomes and clinical status at day 15 could not be derived as planned. Inclusion and exclusion criteria were used to define a cohort that represented the type of patient that would have been eligible to have received remdesivir, and with the greatest potential to benefit from it, according to the existing evidence base. This created a clear analysis cohort with similar baseline level of severity of COVID-19.73\% of patients given remdesivir were excluded - chiefly because their treatment did not start within 24 hours of baseline. We justify their exclusion as the data collection tool could not guarantee determination of clinical status at start of treatment at other times. Other remdesivir patients were excluded because they required respiratory support or ECMO at baseline. These excluded patients are of interest, in the overall assessment of effectiveness, but would have to be the subject of a separate study. Propensity matching was used effectively to select a control group that had a similar profile to remdesivir patients and balanced according to the risk-score balance diagnostic. The control group were slightly older, but had similar clinical frailty scores, and numbers of comorbidities. Propensity score matching is a powerful 
medRxiv preprint doi: https://doi.org/10.1101/2021.06.18.21259072; this version posted June 21 , 2021. The copyright holder for this preprint (which was not certified by peer review) is the author/funder, who has granted medRxiv a license to display the preprint in perpetuity.

It is made available under a CC-BY-NC-ND 4.0 International license .

design tool in an observational study - provided all key factors that increased likelihood of treatment are considered when developing a propensity score model. A priori matching factors were principally demographic and baseline clinical characteristics that might be related to chance of being given remdesivir, or chance of death within 14 days, or both. Several baseline continuous measures were not prespecified in the SAP for inclusion in the development of the propensity score model: oxygen saturation, respiratory rate Glasgow coma score, urea and C-reactive protein (CRP). With hindsight these may have been important to consider, though missing CRP and urea data would have led to at least $20 \%$ of patients being excluded from the matching algorithm. Nevertheless, these variables all contribute to the $4 \mathrm{C}$ mortality score, for which good balance was observed.

It is possible that further benefit could be gained if remdesivir, or a similar orally available direct acting antiviral, could be given earlier in the disease process, when pharyngeal shedding and by inference viral replication in the lower respiratory tract is at its highest. ${ }^{12}$ SARS-CoV-2-infected rhesus macaques were successfully treated when remdesivir dosing was initiated 12 hours after virus inoculum. The authors noted that the efficacy of such direct acting antivirals against acute viral respiratory infections usually drops with time after infection and stressed the importance of dosing humans as quickly as possible. The ACTT- 1 trial ${ }^{15}$ confirmed that benefits associated with remdesivir were larger earlier in the disease course ( $<=10$ days vs $>10$ days). Our study contains too few hospital-acquired patients to explore this hypothesis.

We note that liver dysfunction was increased in the remdesivir group. This is not unexpected, since raised transaminases are an expected adverse event in nucleoside analogues, and indeed alanine aminotransferase (ALT) was elevated in $7 \%$ of remdesivir clinical trial participants. ${ }^{26}$ The current data does not allow us to distinguish the level of severity of this liver dysfunction or whether it was reversible.

Overall, our study does not provide evidence that remdesivir is of benefit in patients hospitalised with severe COVID-19.

\section{Data sharing}

This work uses data provided by patients and collected by the NHS as part of their care and support \#DataSavesLives. ISARIC4C welcomes applications for data and material access through our Independent Data and Material Access Committee (https://isaric4c.net).

\section{Contributors}


medRxiv preprint doi: https://doi.org/10.1101/2021.06.18.21259072; this version posted June 21, 2021. The copyright holder for this preprint (which was not certified by peer review) is the author/funder, who has granted medRxiv a license to display the preprint in perpetuity.

It is made available under a CC-BY-NC-ND 4.0 International license .

Conceptualisation: BN Arch, A Rosala-Hallas, EM Harrison, AP Jones, MG Semple. Formal analysis: BN Arch, A Rosala-Hallas. Writing original draft: BN Arch, D Kovacs, JT Scott. Writing reviewing and editing: BN Arch, JK Baillie, CG Gamble, EM Harrison, AP Jones, PJM Openshaw, JT Scott, MG Semple.

\section{Declaration of interests}

All authors have completed the ICMJE uniform disclosure form at www.icmje.org/coi_disclosure.pdf and declare:

BNA, ARH, APJ and CGG report: the manufacturer of remdesivir, Gilead, is involved in funding trials that the Liverpool Clinical Trials unit is co-ordinating: a randomised controlled trial (HART-CT) that is fully funded by Gilead and sponsored by the University of Liverpool; and a trial (RIAltO) that is part funded by Gilead. APJ is the lead statistician on the HART-CT trial. PJMO reports personal fees from consultancies and from the European Respiratory Society; grants from the Medical Research Council (MRC), MRC Global Challenge Research Fund, EU, NIHR BRC, MRC/GSK, Wellcome Trust, NIHR (Health Protection Research Unit [HPRU] in Respiratory Infection); and is an NIHR senior investigator outside of the submitted work; his role as President of the British Society for Immunology was unpaid but travel and accommodation at some meetings was provided by the Society. MGS reports grants from NIHR UK, MRC UK, and HPRU in Emerging and Zoonotic Infections, University of Liverpool during the conduct of the study.

\section{Acknowledgments}

Dr Emily Granger of the London School of Hygiene and Tropical Medicine, for advice regarding optimal balance diagnostics. Dr Lance Turtle of the University of Liverpool, for insight into clinical decision making during the treatment of COVID-19 patients in hospital.

\section{Funding}

ISARIC4C is funded by two major awards from the Medical Research Council (MRC; grant MC_PC_19059), and The National Institute For Health Research (NIHR; award CO-CIN-01). PJMO is supported by a NIHR Senior Investigator Award [award 201385]. The Liverpool clinical trials unit did not receive any direct funding for this work. DK is funded by UK MRC Precision Medicine Training Grant (MR/N013166/1-LGH/MS/MED2525). The views expressed are those of the authors and not necessarily those of the NHIR, or MRC. 
medRxiv preprint doi: https://doi.org/10.1101/2021.06.18.21259072; this version posted June 21, 2021. The copyright holder for this preprint (which was not certified by peer review) is the author/funder, who has granted medRxiv a license to display the preprint in perpetuity.

It is made available under a CC-BY-NC-ND 4.0 International license .

\section{References}

1. NICE. COVID 19 rapid evidence summary: Remdesivir for treating hospitalised patients with suspected or confirmed COVID-19. 2020.

2. Williamson BN, Feldmann F, Schwarz B, et al. Clinical benefit of remdesivir in rhesus macaques infected with SARS-CoV-2. 2020.

3. Warren TK, Jordan R, Lo MK, et al. Therapeutic efficacy of the small molecule GS-5734 against Ebola virus in rhesus monkeys. Nature 2016; 531(7594): 381-5.

4. Kokic G, Hillen HS, Tegunov D, et al. Mechanism of SARS-CoV-2 polymerase stalling by remdesivir. Nat Commun 2021; 12(1): 279.

5. Sheahan TP, Sims AC, Graham RL, et al. Broad-spectrum antiviral GS-5734 inhibits both epidemic and zoonotic coronaviruses. Sci Trans/ Med 2017; 9(396): eaal3653.

6. Agostini ML, Andres EL, Sims AC, et al. Coronavirus Susceptibility to the Antiviral Remdesivir (GS-5734) Is Mediated by the Viral Polymerase and the Proofreading Exoribonuclease. mBio 2018; 9(2).

7. Bojkova D, McGreig JE, McLaughlin K-M, et al. SARS-CoV-2 and SARS-CoV differ in their cell tropism and drug sensitivity profiles. bioRxiv 2020.

8. De Meyer S, Bojkova D, Cinati J, et al. Lack of Antiviral Activity of Darunavir against SARS-CoV2. 2020.

9. Ko M, Jeon S, Ryu W-S, Kim S. Comparative analysis of antiviral efficacy of FDA-approved drugs against SARS-CoV-2 in human lung cells: Nafamostat is the most potent antiviral drug candidate. 2020. 10. Ellinger B, Bojkova D, Zaliani A, et al. Identification of inhibitors of SARS-CoV-2 in-vitro cellular toxicity in human (Caco-2) cells using a large scale drug repurposing collection. 2020.

11. Dittmar M, Lee JS, Whig K, et al. Drug repurposing screens reveal FDA approved drugs active against SARS-Cov-2. 2020.

12. Sheahan TP, Sims AC, Zhou S, et al. An orally bioavailable broad-spectrum antiviral inhibits SARS-CoV-2 in human airway epithelial cell cultures and multiple coronaviruses in mice. Sci Trans/ Med 2020; 12(541).

13. Pruijssers AJ, George AS, Schäfer A, et al. Remdesivir potently inhibits SARS-CoV-2 in human lung cells and chimeric SARS-CoV expressing the SARS-CoV-2 RNA polymerase in mice. 2020.

14. Humeniuk R, Mathias A, Cao H, et al. Safety, Tolerability, and Pharmacokinetics of Remdesivir, An Antiviral for Treatment of COVID-19, in Healthy Subjects. Clin Trans/ Sci 2020; 13(5): 896-906.

15. Beigel JH, Tomashek KM, Dodd LE, et al. Remdesivir for the Treatment of Covid-19 - Final Report. New England Journal of Medicine 2020.

16. NIAID NIOAaID. STATISTICAL ANALYSIS PLAN for DMID Protocol: 20-0006

Study Title: A Multicenter, Adaptive, Randomized Blinded Controlled Trial of the Safety and Efficacy of Investigational Therapeutics for the Treatment of COVID-19 in Hospitalized Adults v3.0. 2020.

17. Pan $\mathrm{H}$, Peto $\mathrm{R}$, Karim QA, et al. Repurposed antiviral drugs for COVID-19 -interim WHO SOLIDARITY trial results. medRxiv 2020: 2020.10.15.20209817.

18. WHO. SOLIDARITY core protocol for therapeutics. 26/04/2020. https://www.who.int/publications/i/item/who-working-group-core-protocol-for-therapeuticsagainst-covid19 (accessed 04/05/2021.

19. Docherty $A B$, Harrison EM, Green CA, et al. Features of 20133 UK patients in hospital with covid-19 using the ISARIC WHO Clinical Characterisation Protocol: prospective observational cohort study. BMJ 2020; 369: m1985.

20. ISARIC WHO CCP-UK Study materials https://isaric4c.net/protocols/ (accessed 04/05/2021.

21. Interim Clinical Commissioning Policy: Remdesivir for patients hospitalised with COVID-19 (adults and children 12 years and older) Version 2.

22. Remdesivir Effectiveness Study Statistical Analysis Plan https://isaric4c.net/outputs/remdesivir/ (accessed 04/05/2021. 
medRxiv preprint doi: https://doi.org/10.1101/2021.06.18.21259072; this version posted June 21, 2021. The copyright holder for this preprint (which was not certified by peer review) is the author/funder, who has granted medRxiv a license to display the preprint in perpetuity.

It is made available under a CC-BY-NC-ND 4.0 International license .

23. Stuart EA. Matching methods for causal inference: A review and a look forward. Stat Sci 2010; 25(1): 1-21.

24. Stuart EA, Lee BK, Leacy FP. Prognostic score-based balance measures can be a useful diagnostic for propensity score methods in comparative effectiveness research. J Clin Epidemiol 2013; 66(8 Suppl): S84-S90.e1.

25. Knight SR, Ho A, Pius R, et al. Risk stratification of patients admitted to hospital with covid-19 using the ISARIC WHO Clinical Characterisation Protocol: development and validation of the $4 \mathrm{C}$ Mortality Score. BMJ 2020; 370: m3339.

26. Goldman JD, Lye DCB, Hui DS, et al. Remdesivir for 5 or 10 Days in Patients with Severe Covid19. N Engl J Med 2020; 383(19): 1827-37. 
medRxiv preprint doi: https://doi.org/10.1101/2021.06.18.21259072; this version posted June 21 , 2021. The copyright holder for this preprint (which was not certified by peer review) is the author/funder, who has granted medRxiv a license to display the preprint in perpetuity.

It is made available under a CC-BY-NC-ND 4.0 International license .

\section{Figures and Tables: Main article}

Figure 1: CONSORT style flow-chart summarising the flow of patients through the analysis stages

\section{Cohort Ascertainment}

Assessed for eligibility $(n=39,330)$

Excluded $(n=30,052)$

Reasons (not mutually exclusive):

- Not recorded needing oxygen at baseline $(n=20,517)$

- Chronic Kidney disease $(n=7,182)$

- Required ventilation during $1^{\text {st }} 24 \mathrm{hrs}(\mathrm{n}=4,657)$

- If had RDV, was not initiated within 24 hours of baseline $(n=2,516)$

- $<18$ yrs old $(n=769)$

- Pregnant $(n=667)$

- Withdrew consent to be part of any study $(n=5)$

- Other, if none of the above $(n=3,037)$




medRxiv preprint doi: https://doi.org/10.1101/2021.06.18.21259072; this version posted June 21 , 2021. The copyright holder for this preprint (which was not certified by peer review) is the author/funder, who has granted medRxiv a license to display the preprint in perpetuity.

It is made available under a CC-BY-NC-ND 4.0 International license.

Figure 2: Number of patients hospitalised in the UK due to COVID-19, recorded in ISARIC4C Database, and of these the number eligible for inclusion in this study (7-day rolling average)

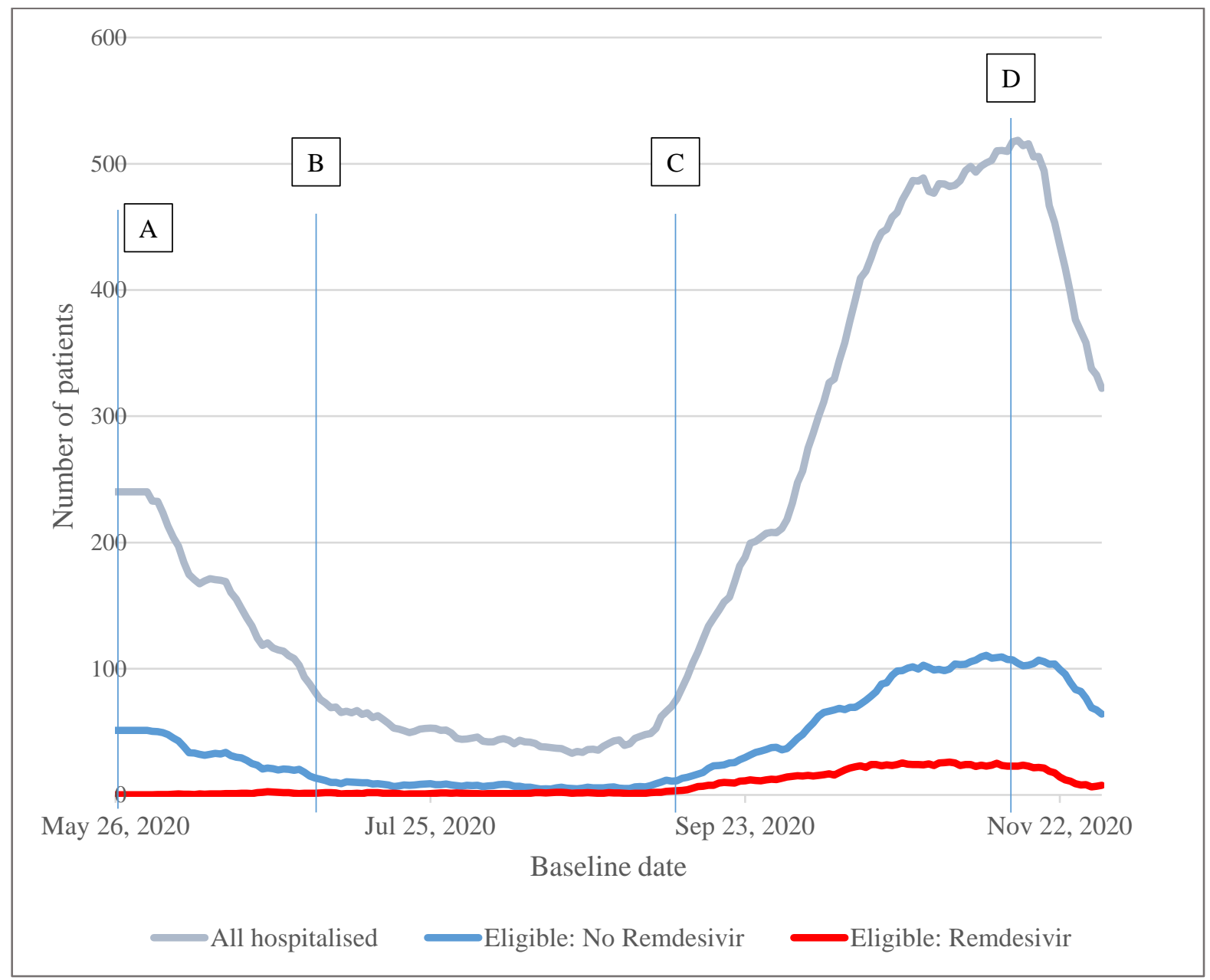

Key time-points: A: Early access to medicine (EAMS) starts; B: EAMS ends and remdesivir commissioned for routine use in the UK; $C$ : guidelines given for co-administration of corticosteroids; D: guidelines implemented 'consider stopping remdesivir if: the patient clinically improves and no longer requires supplemental oxygen 72 hours after commencement of treatment; or the patient continues to deteriorate despite 48 hours of sustained mechanical ventilation.' 
Table 1 Baseline characteristics (statistics are $n(\%)$ unless otherwise stated)

\begin{tabular}{|c|c|c|c|c|c|c|}
\hline & \multicolumn{3}{|c|}{$\begin{array}{l}\text { Full Analysis Cohort } \\
\qquad(\mathbf{n}=\mathbf{9}, 278)\end{array}$} & \multicolumn{3}{|c|}{$\begin{array}{l}\text { Matched Cohort } \\
\quad(n=6,513)\end{array}$} \\
\hline & $\begin{array}{l}\text { Remdesivir } \\
(\mathrm{N}=\mathbf{1 , 5 5 2})\end{array}$ & $\begin{array}{c}\text { Control } \\
(\mathrm{N}=7,726)\end{array}$ & $\begin{array}{c}\text { All } \\
(\mathrm{N}=9,278)\end{array}$ & $\begin{array}{l}\text { Remdesivir } \\
(\mathrm{N}=\mathbf{1 , 5 4 9})\end{array}$ & $\begin{array}{c}\text { Control } \\
(\mathrm{N}=\mathbf{4 , 9 6 4 )}\end{array}$ & $\begin{array}{c}\text { All } \\
(\mathrm{N}=6,513)\end{array}$ \\
\hline \multicolumn{7}{|l|}{ Age (years) } \\
\hline Mean (SD) & $61 \cdot 7(14 \cdot 4)$ & $69 \cdot 1(16 \cdot 8)$ & $67 \cdot 9(16 \cdot 6)$ & $61 \cdot 7(14 \cdot 4)$ & $63 \cdot 5(15 \cdot 9)$ & $63 \cdot 1(15 \cdot 6)$ \\
\hline Median (IQR) & $61 \cdot 7(52 \cdot 3,72 \cdot 5)$ & $72 \cdot 0(57 \cdot 7,82 \cdot 2)$ & $70 \cdot 2(56 \cdot 6,81 \cdot 0)$ & $61 \cdot 6(52 \cdot 3,72 \cdot 5)$ & $64 \cdot 8(53 \cdot 4,75 \cdot 2)$ & $63 \cdot 8(53 \cdot 1,74 \cdot 7)$ \\
\hline \multicolumn{7}{|l|}{ Age (years) } \\
\hline $18-30$ & $33(2 \cdot 1 \%)$ & $196(2 \cdot 5 \%)$ & $229(2 \cdot 5 \%)$ & $33(2 \cdot 1 \%)$ & $168(3 \cdot 4 \%)$ & $201(3 \cdot 1 \%)$ \\
\hline $31-40$ & $88(5 \cdot 7 \%)$ & $349(4 \cdot 5 \%)$ & $437(4 \cdot 7 \%)$ & $88(5 \cdot 7 \%)$ & $301(6 \cdot 1 \%)$ & $389(6 \cdot 0 \%)$ \\
\hline $41-50$ & $224(14 \cdot 4 \%)$ & $634(8 \cdot 2 \%)$ & $858(9 \cdot 2 \%)$ & $223(14 \cdot 4 \%)$ & $554(11 \cdot 2 \%)$ & $777(11 \cdot 9 \%)$ \\
\hline $51-60$ & $388(25 \cdot 0 \%)$ & $1,151(14 \cdot 9 \%)$ & $1,539(16 \cdot 6 \%)$ & $388(25 \cdot 0 \%)$ & $1,027(20 \cdot 7 \%)$ & $1,415(21 \cdot 7 \%)$ \\
\hline $61-70$ & $385(24 \cdot 8 \%)$ & $1,345(17 \cdot 4 \%)$ & $1,730(18 \cdot 6 \%)$ & $385(24 \cdot 9 \%)$ & $1,133(22 \cdot 8 \%)$ & $1,518(23 \cdot 3 \%)$ \\
\hline $71-80$ & $278(17 \cdot 9 \%)$ & $1,887(24 \cdot 4 \%)$ & $2,165(23 \cdot 3 \%)$ & $276(17 \cdot 8 \%)$ & $1,127(22 \cdot 7 \%)$ & $1,403(21 \cdot 5 \%)$ \\
\hline$>80$ & $156(10 \cdot 1 \%)$ & $2,164(28 \cdot 0 \%)$ & $2,320(25 \cdot 0 \%)$ & $156(10 \cdot 1 \%)$ & $654(13 \cdot 2 \%)$ & $810(12 \cdot 4 \%)$ \\
\hline Male & $1,005(64 \cdot 8 \%)$ & $4,264(55 \cdot 2 \%)$ & $5,269(56 \cdot 8 \%)$ & $1,005(64 \cdot 9 \%)$ & $3,037(61 \cdot 2 \%)$ & $4,042(62 \cdot 1 \%)$ \\
\hline Ethnicity $^{(a)}$ & $(\mathrm{N}=1,336)$ & $(\mathrm{N}=6,903)$ & $(\mathrm{N}=8,239)$ & $(\mathrm{N}=1,336)$ & $(\mathrm{N}=4,376)$ & $(\mathrm{N}=5,712)$ \\
\hline White & $1,046(78 \cdot 3 \%)$ & $5,829(84 \cdot 4 \%)$ & $6,875(83 \cdot 4 \%)$ & $1,046(78 \cdot 3 \%)$ & $3506(80 \cdot 1 \%)$ & $4,552(79 \cdot 7 \%)$ \\
\hline Asian & $153(11 \cdot 5 \%)$ & $552(8 \cdot 0 \%)$ & $705(8 \cdot 6 \%)$ & $153(11 \cdot 5 \%)$ & $457(10 \cdot 4 \%)$ & $610(10 \cdot 7 \%)$ \\
\hline Black & $38(2 \cdot 8 \%)$ & $122(1 \cdot 8 \%)$ & $160(1.9 \%)$ & $38(2 \cdot 8 \%)$ & $97(2 \cdot 2 \%)$ & $135(2 \cdot 4 \%)$ \\
\hline Other & $99(7 \cdot 4 \%)$ & $400(5 \cdot 8 \%)$ & $499(6 \cdot 1 \%)$ & $99(7 \cdot 4 \%)$ & $316(7 \cdot 2 \%)$ & $415(7 \cdot 3 \%)$ \\
\hline $\begin{array}{l}\text { Clinically extremely vulnerable } \\
\text { status }^{(\mathbf{b})}\end{array}$ & $(\mathrm{N}=1,512)$ & $(\mathrm{N}=7,474)$ & $(\mathrm{N}=8,986)$ & $(\mathrm{N}=1,511)$ & $(\mathrm{N}=4,835)$ & $(\mathrm{N}=6,346)$ \\
\hline None & $1,411(93 \cdot 3 \%)$ & $6,722(89 \cdot 9 \%)$ & $8,133(90 \cdot 5 \%)$ & $1,410(93 \cdot 3 \%)$ & $4,460(92 \cdot 2 \%)$ & $5,870(92 \cdot 5 \%)$ \\
\hline Cancer & $31(2 \cdot 1 \%)$ & $236(3 \cdot 2 \%)$ & $267(3 \cdot 2 \%)$ & $31(2 \cdot 1 \%)$ & $111(2 \cdot 3 \%)$ & $142(2 \cdot 2 \%)$ \\
\hline Severe respiratory condition & $27(1 \cdot 8 \%)$ & $284(3 \cdot 8 \%)$ & $311(3 \cdot 5 \%)$ & $27(1 \cdot 8 \%)$ & $129(2 \cdot 7 \%)$ & $156(2 \cdot 5 \%)$ \\
\hline Immunosuppression therapy & $35(2 \cdot 3 \%)$ & $186(2 \cdot 5 \%)$ & $221(2 \cdot 5 \%)$ & $35(2 \cdot 3 \%)$ & $104(2 \cdot 2 \%)$ & $139(2 \cdot 2 \%)$ \\
\hline Other & $8(0 \cdot 5 \%)$ & $46(0 \cdot 6 \%)$ & $54(0 \cdot 6 \%)$ & $8(0 \cdot 5 \%)$ & $31(0 \cdot 6 \%)$ & $39(0 \cdot 6 \%)$ \\
\hline
\end{tabular}

Comorbidities 


\begin{tabular}{|c|c|c|c|c|c|c|}
\hline None & $252(16 \cdot 2 \%)$ & $704(9 \cdot 1 \%)$ & $956(10 \cdot 3 \%)$ & $252(16 \cdot 3 \%)$ & $613(12 \cdot 3 \%)$ & $865(13 \cdot 3 \%)$ \\
\hline Diabetes & $386(24 \cdot 9 \%)$ & $1,826(23 \cdot 6 \%)$ & $2,212(23 \cdot 8 \%)$ & $386(24 \cdot 9 \%)$ & $1,208(24 \cdot 3 \%)$ & $1,594(24 \cdot 5 \%)$ \\
\hline Hypertension & $584(37 \cdot 6 \%)$ & $3,188(41 \cdot 3 \%)$ & $3,772(40 \cdot 7 \%)$ & $584(37 \cdot 7 \%)$ & $1,874(37 \cdot 8 \%)$ & $2,458(37 \cdot 7 \%)$ \\
\hline Obesity & $291(18 \cdot 8 \%)$ & $865(11 \cdot 2 \%)$ & $1,156(12 \cdot 5 \%)$ & $291(18 \cdot 8 \%)$ & $725(14 \cdot 6 \%)$ & $1,016(15 \cdot 6 \%)$ \\
\hline Chronic Cardiac Disease & $262(16 \cdot 9 \%)$ & $2,086(27 \cdot 0 \%)$ & $2,348(25 \cdot 3 \%)$ & $262(16 \cdot 9 \%)$ & $995(20 \cdot 0 \%)$ & $1,257(19 \cdot 3 \%)$ \\
\hline Chronic Pulmonary Disease & $219(14 \cdot 1 \%)$ & $1,398(18 \cdot 1 \%)$ & $1,617(17 \cdot 4 \%)$ & $218(14 \cdot 1 \%)$ & $770(15 \cdot 5 \%)$ & $988(15 \cdot 2 \%)$ \\
\hline Asthma & $261(16 \cdot 8 \%)$ & $1,091(14 \cdot 1 \%)$ & $1,352(14 \cdot 6 \%)$ & $261(16 \cdot 8 \%)$ & $754(15 \cdot 2 \%)$ & $1,015(15 \cdot 6 \%)$ \\
\hline Other & $328(21 \cdot 1 \%)$ & $3,057(39 \cdot 6 \%)$ & $3,385(36 \cdot 5 \%)$ & $328(21 \cdot 2 \%)$ & $1,616(32 \cdot 6 \%)$ & $1,944(29 \cdot 8 \%)$ \\
\hline \multirow[t]{4}{*}{ Number of key comorbidities ${ }^{(\mathbf{c})}$} & $(\mathrm{N}=1,546)$ & $(\mathrm{N}=7,631)$ & $(\mathrm{N}=\mathbf{9 , 1 7 7})$ & $(\mathrm{N}=\mathbf{1 , 5 4 2})$ & $(\mathrm{N}=4,918)$ & $(N=6,460)$ \\
\hline & $472(30 \cdot 5 \%)$ & $1,974(25 \cdot 9 \%)$ & $2,446(26 \cdot 7 \%)$ & $470(30 \cdot 5 \%)$ & $1,461(29 \cdot 7 \%)$ & $1,931(29 \cdot 9 \%)$ \\
\hline & $471(30 \cdot 5 \%)$ & $2,486(32 \cdot 6 \%)$ & $2,957(32 \cdot 2 \%)$ & $470(30 \cdot 5 \%)$ & $1,568(31 \cdot 9 \%)$ & $2,038(31 \cdot 5 \%)$ \\
\hline & $603(39 \cdot 0 \%)$ & $3,171(41 \cdot 6 \%)$ & $3,774(41 \cdot 1 \%)$ & $603(39 \cdot 1 \%)$ & $1,889(38 \cdot 4 \%)$ & $2,492(38 \cdot 6 \%)$ \\
\hline \multicolumn{7}{|l|}{ Where COVID was acquired } \\
\hline Community & $1,523(98 \cdot 1 \%)$ & $6,920(89 \cdot 6 \%)$ & $8,443(91 \cdot 0 \%)$ & $1,520(98 \cdot 1 \%)$ & $4,846(97 \cdot 6 \%)$ & $6,366(97 \cdot 7 \%)$ \\
\hline Hospital & $23(1 \cdot 5 \%)$ & $704(9 \cdot 1 \%)$ & $727(7 \cdot 8 \%)$ & $23(1 \cdot 5 \%)$ & $94(1 \cdot 9 \%)$ & $117(1 \cdot 8 \%)$ \\
\hline Unknown & $6(0 \cdot 4 \%)$ & $102(1 \cdot 3 \%)$ & $108(1 \cdot 2 \%)$ & $6(0 \cdot 4 \%)$ & $24(0 \cdot 5 \%)$ & $30(0 \cdot 5 \%)$ \\
\hline \multicolumn{7}{|c|}{ Days since symptom onset (symptomatic patients only): } \\
\hline Community acquired & $(\mathrm{N}=1,506)$ & $(\mathrm{N}=6,276)$ & $(\mathrm{N}=7,782)$ & $(\mathrm{N}=\mathbf{1 , 5 0 3})$ & $(\mathrm{N}=\mathbf{4 , 4 4 2})$ & $(\mathrm{N}=5,945)$ \\
\hline \multirow[b]{2}{*}{ Hospital acquired } & $7(4,9)$ & $5(2,9)$ & $6(2,9)$ & $7(4,9)$ & $6(2,9)$ & $6(3,9)$ \\
\hline & $(\mathrm{N}=11)$ & $(\mathrm{N}=258)$ & $(\mathrm{N}=269)$ & $(\mathrm{N}=11)$ & $(\mathrm{N}=\mathbf{2 7})$ & $(\mathrm{N}=38)$ \\
\hline Median (IQR) & $0(0,4)$ & $0(0,1)$ & $0(0,1)$ & $0(0,4)$ & $0(0,1)$ & $0(0,1)$ \\
\hline \multirow[t]{2}{*}{ Admitted to $\mathrm{HDU} / \mathrm{ICU}$ at baseline } & $(\mathrm{N}=\mathbf{1 , 5 2 6})$ & $(\mathrm{N}=7,558)$ & $(\mathrm{N}=9,084)$ & $(\mathrm{N}=\mathbf{1 , 5 2 4})$ & $(\mathrm{N}=4,875)$ & $(\mathrm{N}=6,399)$ \\
\hline & $90(5 \cdot 9 \%)$ & $145(1 \cdot 9 \%)$ & $235(2 \cdot 6 \%)$ & $90(5 \cdot 9 \%)$ & $136(2 \cdot 8 \%)$ & $226(3 \cdot 5 \%)$ \\
\hline Clinical Frailty Score & $(\mathrm{N}=\mathbf{7 8 0})$ & $(\mathrm{N}=3,965)$ & $(\mathrm{N}=\mathbf{4 , 7 4 5 )}$ & $(\mathrm{N}=779)$ & $(\mathrm{N}=\mathbf{2 , 4 6 8})$ & $(\mathrm{N}=\mathbf{4 , 7 4 5})$ \\
\hline \multirow{2}{*}{ 4C Mortality Score } & $3(2,4)$ & $4(2,6)$ & $4(2,6)$ & $3(2,4)$ & $3(2,5)$ & $3(2,4)$ \\
\hline & $(\mathrm{N}=1,242)$ & $(\mathrm{N}=5, \mathbf{4 4 3})$ & $(\mathrm{N}=6,685)$ & $(\mathrm{N}=\mathbf{1 , 2 4 0})$ & $(\mathrm{N}=3,692)$ & $(\mathrm{N}=4,932)$ \\
\hline Median (IQR) & $9(6,12)$ & $10(7,12)$ & $10(7,12)$ & $9(6,12)$ & $9(6,12)$ & $9(6,12)$ \\
\hline \multirow{2}{*}{ Oxygen Saturation (\%) } & $(\mathrm{N}=\mathbf{1 , 5 4 9})$ & $(\mathrm{N}=7,716)$ & $(\mathrm{N}=9,265)$ & $(\mathrm{N}=\mathbf{1 , 5 4 6})$ & $(\mathrm{N}=4,959)$ & $(\mathrm{N}=\mathbf{6 , 5 0 5})$ \\
\hline & $92(89,94)$ & $94(91,95)$ & $93(90,95)$ & $92(89,94)$ & $94(91,95)$ & $93(90,95)$ \\
\hline
\end{tabular}




\begin{tabular}{|c|c|c|c|c|c|c|}
\hline Median (IQR) & $24(21,28)$ & $22(20,26)$ & $22(20,27)$ & $24(21,28)$ & $22(20,27)$ & $23(20,28)$ \\
\hline Glasgow Coma Score: n (\%) & $(\mathrm{N}=\mathbf{1 , 5 1 1})$ & $(\mathrm{N}=7, \mathbf{5 1 0})$ & $(\mathrm{N}=9,021)$ & $(\mathrm{N}=\mathbf{1 , 5 0 8})$ & $(\mathrm{N}=4,846)$ & $(\mathrm{N}=6,354)$ \\
\hline Equal to 15 & $1,462(96 \cdot 8 \%)$ & $6,826(90 \cdot 9 \%)$ & $8,288(91 \cdot 9 \%)$ & $1,459(96 \cdot 8 \%)$ & $4,489(92 \cdot 6 \%)$ & $5,948(93 \cdot 6 \%)$ \\
\hline Urea $(\mathrm{mmol} / \mathrm{L})$ & $(\mathrm{N}=1,350)$ & $(\mathrm{N}=6,192)$ & $(\mathrm{N}=7,542)$ & $(\mathrm{N}=1,348)$ & $(\mathrm{N}=4,127)$ & $(\mathrm{N}=\mathbf{5 , 4 7 5})$ \\
\hline Median (IQR) & $5 \cdot 7(4 \cdot 3,7 \cdot 7)$ & $6 \cdot 1(4 \cdot 5,8 \cdot 6)$ & $6 \cdot 0(4 \cdot 4,8 \cdot 5)$ & $5 \cdot 7(4 \cdot 3,7 \cdot 7)$ & $5 \cdot 7(4 \cdot 2,7 \cdot 9)$ & $5 \cdot 7(4 \cdot 2,7 \cdot 9)$ \\
\hline C-Reactive Protein (mg/L) & $(\mathrm{N}=\mathbf{1 , 3 6 5})$ & $(\mathrm{N}=6,104)$ & $(\mathrm{N}=7, \mathbf{4 6 9})$ & $(\mathrm{N}=1,362)$ & $(\mathrm{N}=4,102)$ & $(\mathrm{N}=\mathbf{5 , 4 6 4})$ \\
\hline Median (IQR) & $106(61,172)$ & $72(30,134)$ & $79(34,140)$ & $106(61,172)$ & $79(34,140)$ & $85(40,148)$ \\
\hline
\end{tabular}

(a) Defined to be mutually exclusive: Asian = any ticked from Arab, East/South/West Asian; Black = Black ticked, but no Asian categories; White = 'White ticked', but not any Asian or Black categories; Other = not categorised Asian, Black or White, but at least one category ticked in any other box except 'Unknown'.

(b) Categories are not mutually exclusive. No clinically vulnerabilities: all options ticked 'No'; Clinically vulnerable unknown: no boxes are ticked 'Yes', and any level of missingness.

(c) Key comorbidities: Diabetes, Hypertension, Obesity, CCD, CPD, Asthma. 
Table 2: Analysis of binary/ordinal outcomes

\begin{tabular}{|c|c|c|c|c|c|c|}
\hline Outcome & Incidence & $\begin{array}{l}\text { Number } \\
\text { included } \\
\text { in model }\end{array}$ & Events & $\begin{array}{c}\text { Adjusted } \\
\text { Odds-ratio }^{(\mathbf{a})}\end{array}$ & $95 \% \mathrm{CI}$ & p-value \\
\hline \multicolumn{7}{|l|}{ 14-day mortality } \\
\hline Remdesivir & $9 \cdot 3 \%(140 / 1,502)$ & 1,499 & 139 & $0 \cdot 8$ & $(0 \cdot 60,1 \cdot 07)$ & $0 \cdot 116$ \\
\hline Control & $12 \cdot 0 \%(565 / 4,728)$ & 4,693 & 561 & 1 & - & \\
\hline \multicolumn{7}{|l|}{ 28-day mortality } \\
\hline Remdesivir & $13 \cdot 6 \%(203 / 1,491)$ & 1,488 & 201 & $0 \cdot 77$ & $(0 \cdot 60,0 \cdot 98)$ & $0 \cdot 034$ \\
\hline Control & $16 \cdot 6 \%(777 / 4,676)$ & 4,641 & 773 & 1 & - & \\
\hline \multicolumn{7}{|c|}{ Clinical status at day $15(+/-2 \text { days })^{(\mathbf{b})}$} \\
\hline Remdesivir & - & 1,496 & - & $0 \cdot 90$ & $(0 \cdot 78,1 \cdot .06)$ & $0 \cdot 230$ \\
\hline Control & - & 4,689 & - & 1 & - & \\
\hline \multicolumn{7}{|c|}{ Use of any non-invasive ventilation during hospitalisation post baseline } \\
\hline Remdesivir & $28 \cdot 8 \%(431 / 1,496)$ & 1,496 & 437 & $2 \cdot 7$ & $(2 \cdot 18,3 \cdot 35)$ & $<0 \cdot 0001$ \\
\hline Control & $10 \cdot 2 \%(466 / 4,587)$ & 4,564 & 474 & 1 & - & \\
\hline \multicolumn{7}{|c|}{ Use of any mechanical ventilation or ECMO during hospitalisation post baseline } \\
\hline Remdesivir & $6 \cdot 8 \%(106 / 1,498)$ & 1,497 & 109 & $1 \cdot 72$ & $(1 \cdot 20,2 \cdot 45)$ & 0.003 \\
\hline Control & $3 \cdot 3 \%(153 / 4,602)$ & 4,576 & 160 & 1 & - & \\
\hline \multicolumn{7}{|c|}{ Any acute renal injury or acute renal failure during hospitalisation post baseline } \\
\hline Remdesivir & $8 \cdot 3 \%(129 / 1,503)$ & 1,499 & 129 & $0 \cdot 91$ & $(0 \cdot 68,1 \cdot 20)$ & $0 \cdot 487$ \\
\hline Control & $8 \cdot 6 \%(427 / 4,964)$ & 4,637 & 425 & 1 & - & \\
\hline \multicolumn{7}{|c|}{ Any liver dysfunction during hospitalisation post baseline } \\
\hline Remdesivir & $8 \cdot 6 \%(124 / 1,445)$ & 1,443 & 124 & $1 \cdot 51$ & $(1 \cdot 19,1 \cdot 92)$ & $0 \cdot 0008$ \\
\hline Control & $5 \cdot 4 \%(242 / 4,504)$ & 4,483 & 241 & 1 & - & \\
\hline
\end{tabular}

(a) Each odds ratio presented is estimated from a separate model, each adjusted for: baseline age-group ( $<50,50-69,60-69,70-79,80+)$, sex, number of key comorbidities $(0,1,2+)$ [where key comorbidities are: any diabetes, hypertension, obesity, CCD, CPD, asthma], dexamethasone use during hospitalisation (Yes, No, Unknown), Viral Pneumonia recorded in the complications CRF (Yes, No, Unknown). Covariate parameter estimates are not published here, as these are not the subject of this study.

(b) Proportional odds-ratio presented - odds of being classified in a worse clinical status at day 15 for Remdesivir compared with Control. 
Table 3: Analysis of time-to-event outcomes

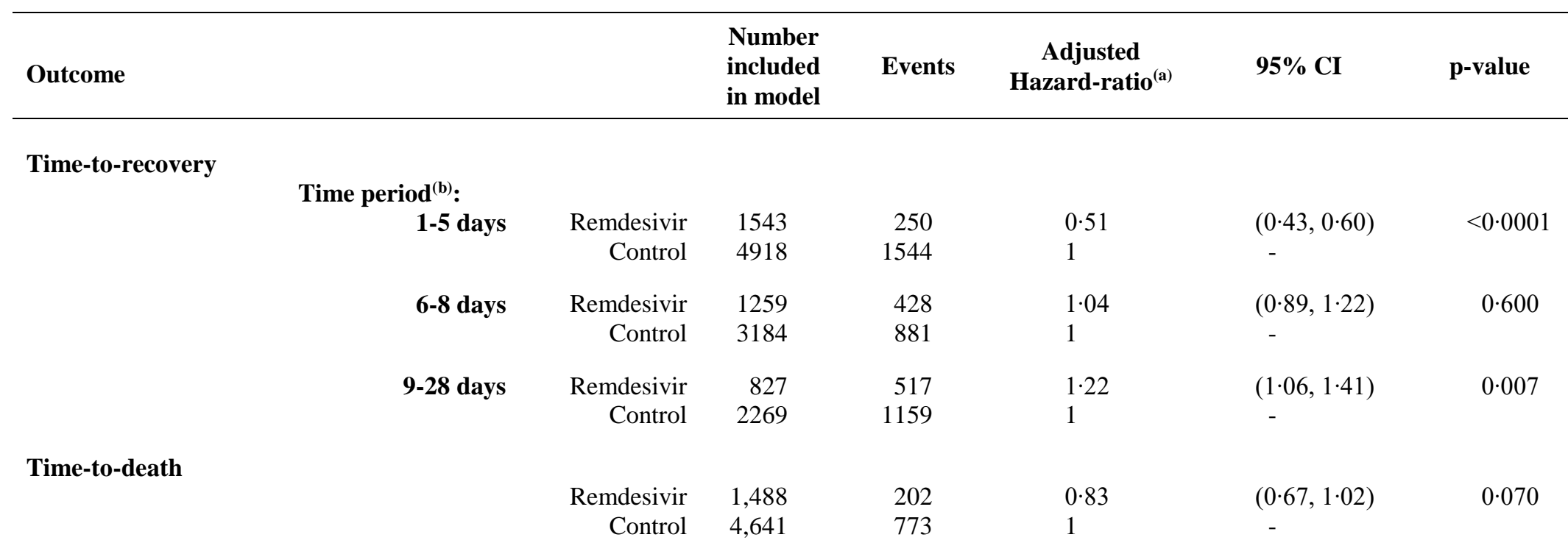

(a) Each hazard ratio presented is estimated from a separate model, each adjusted for: baseline age-group ( $<50,50-69,60-69,70-79,80+)$, sex, no. of key comorbidities $(0,1,2+)$ [where key comorbidities are: any diabetes, hypertension, obesity, CCD, CPD, asthma], dexamethasone use during hospitalisation (Yes, No, Unknown), Viral Pneumonia recorded in the complications CRF (Yes, No, Unknown). Covariate parameter estimates are not published here, as these are not the subject of this study.

(b) Time intervals are chosen such that approximately one third of recoveries took place in each interval. The sample size decreases with each subsequent time-period, as those who recover or are censored prior to the time-period are excluded from the model. 
Figure 3: Kaplan-Meier curves showing (A) time-to-recovery, and (B) time-to-death, during first 28 days post baseline, by treatment group

(A)

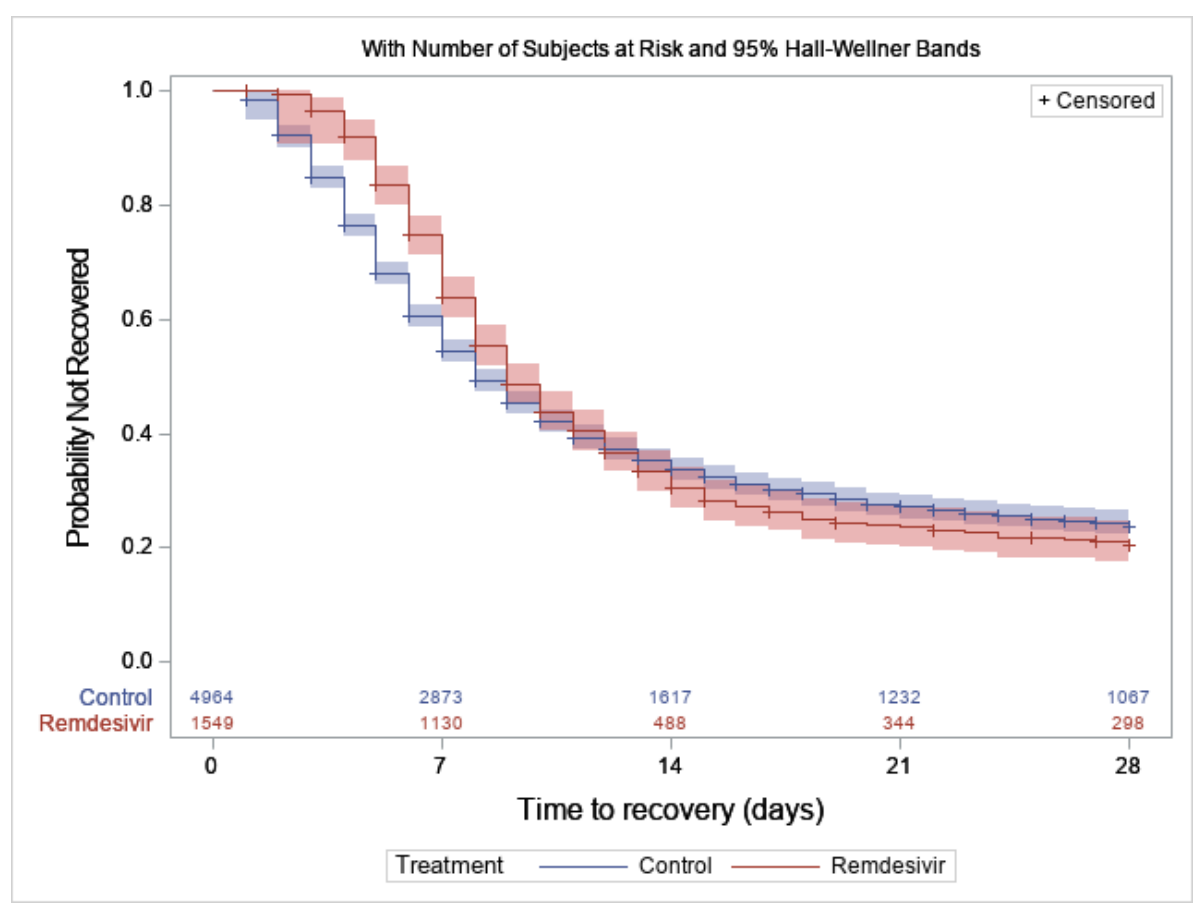

(B)

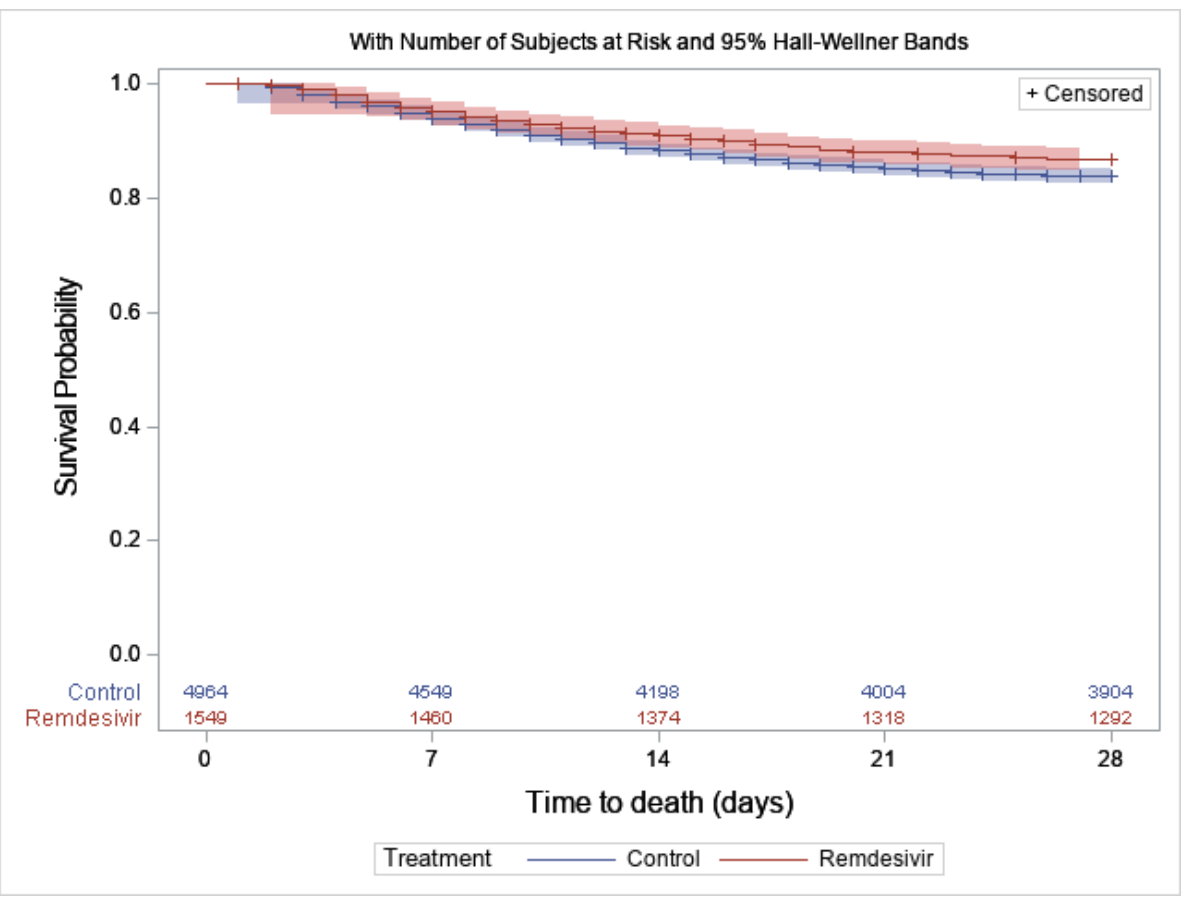

